\title{
USE OF SUSTAINABLE TOURISM INDICATORS FOR RURAL COASTAL COMMUNITIES: A REVIEW
}

\author{
CÉSAR DANIEL AGUILAR-BECERRA, OSCAR FRAUSTO-MARTÍNEZ, HERNANDO AVILEZ PINEDA \& \\ JOSÉ LUIS ROSAS ACEVEDO \\ Universidad Autónoma de Guerrero, México and Universidad de Quintana Roo, México
}

\begin{abstract}
The purpose of this study is to examine the degree of consolidation the sustainable tourism indicators have when applied to Coastal Rural Communities (CRC), with the aim of identifying these indicator's roles and the basic elements that each indicator most fulfills, in order to monitor and control the CRC. The conceptual and methodological frameworks were identified from the global and local perspectives, asking the question: How and who are developing sustainable coastal rural communities within the CRC? Pursuit of scientific information about the topic was carried out throughout four digital repositories: the Wiley online library (17 articles), the Web of Science (6 articles), academic Google (29 articles), and Scopus (20 articles). In total, we recognized 72 articles according to their title parameters and keywords. Out of all the studies, only $15 \%$ focus on our definition, studying the sustainable indicators in coastal areas, but acknowledge 580 indicators that are grouped into the three basic components of sustainability: those that are economical, socio-cultural or environmental. The databases used indicate that there is little literature on topics related to Sustainable Tourism Indicators (STI) in CRC. Finally, the criteria and codes we established for the analysis of the articles allow us to have a clear overview about the process of design, application and evaluation of STI in CRC. It is understood that indicators can be applied in different territorial contexts; however, it is necessary to have a specific foundation, so that the indicators can be compared in dissimilar stages.
\end{abstract}

Keywords: coastal rural communities, literature analysis, review, sustainability, sustainability indicators, tourism.

\section{INTRODUCTION}

Tourism is one of the economic activities with the greatest growth in the world [1]. It has considerable advantages for the prosperous development of the regions where it is built up (as an employment generator and for quality of life); however, it is also related to disadvantages, due to negative impacts that arise, because non-planned tourism growth brings with it the degradation and fragmentation of natural, social and economic environments [2].

Having concerns and studies about the impact of tourism through indicators is not a new topic; there are a great number of studies about the use and applications of indicators to determine the sustainability of tourism [3]; however, these systematic indicators are mostly designed for destinations that are already consolidated or from large masses, but completely forgetting about, for instance, its application in coastal rural communities (CRC). Moreover, there are studies that have been carried out in different parts of the world that are directed to coastal areas [4], [5]: these could serve as a starting point to illustrate the degree of level of maturity of design, application and assessment of sustainable tourism indicators (STI) and CRC. Because of that, our general objective for this study is based on examining the literature regarding the application of sustainable tourism indicators in CRC. Our objective was to identify the main elements of good indicators, thought out for these areas. The methodological and conceptual frameworks about the use of these tools form the global and local perspectives, taking up the research question: Who worked on this and 
how are the sustainable tourism indicators being developed for CRCs? Moreover, how can proper indicators be developed and applied in CRCs?

This review is divided into four important sections:

1. The first one is the conceptual framework where the CRC is contextualized, with outlining of tourism development, its effects and the important criteria for the selection of a good indicator;

2. The second one engages the methodology applied;

3. The third one encompasses the results and discussion; and

4. Finally, the fourth one is about the conclusions drawn by the article.

\section{CONCEPTUAL FRAMEWORK}

Having tourism in literary review assignments is important, because it allows us to understand this economic activity from the different, multi-disciplinary perspective of current applied research [6]. In this tenor, there are three sustainable tourism indicators that have been analyzed in scientific reviews during the last 10 years, from different perspectives. For instance, Tanguay et al. [7] base their work in reviewing indicators applied by experts, achieving a list of indicators that are to be applied to different destinations, from a developmental, sustainable perspective. Torres-Delgado and Saarinen [8], in their analysis of indicators, sought to examine the roles of these in the development of sustainability, identifying characteristics and challenges by each indicator's implementation into the tourism development and research fields. Falatooni et al. [9] presents, through his review, an alternative approach that considers compound indicators, by using the frequency of each indicator that is relevant to the evaluation of a tourist destination.

\subsection{Coastal Rural Communities}

The CRC, by their dimension, represent disadvantaged areas where one can strive to implement sustainable management properly, upon their development. Rural communities are characterized by having human settlements of under 10,000 inhabitants: These represent $70 \%$ of the world's population; however, in countries like Mexico, these rural communities may have fewer than 2,500 inhabitants [10]. The main characteristics of these communities are that they depend on agriculture, cattle-raising, fishing, as well as transformation and merchandising of food supplies linked to a great cultural, social and economic variety [11]. For this study, we conceptualized all those communities with less than 2,500 individuals as CRC with geographical conditions linked to ocean-ground interactions with socio-cultural and economical characteristics, whose appeal is auspicious for the development and uplift from tourism.

\subsection{Tourism in coastal rural areas}

On the other hand, tourist activity is characterized by its versatility and diversification of segments. Tourism segmentation in rural areas is found in different forms: rural tourism, green tourism, communitarian tourism, ecotourism, nature tourism, among others [12]. The $\mathrm{CRC}$ is associated with the tourism of sun and beach, an activity that has been a determining factor for the abandonment of primary economic activity [13]. With the arrival of tourism, communities adopt it as their primary source of income; however, if tourism is not planned when in the transition process, it considerably increases the vulnerability of host communities, which can become susceptible to negative impacts in the development process [14]. 


\subsection{Tourism impacts within the CRC}

It is arguable that there is no economic activity within coastal areas that does not produce a negative impact on the environment. Tourism, particularly regarding sun and beach, is an activity that is deepening in these areas and is currently found within a growing context of competence, in which new destinations will arise [15]. A lack of planning can lead to coastal environments being impacted [16].

Tourism's impacts are different for every destination [17]. The coastal rural environment is very fragile and can easily be damaged by different scales of touristic use. For example, there is localized pollution, loss of natural and cultural resources, changes in soil use, anarchic growth and urban displacement. Those impacts bring serious consequences within the environmental, economic and socio-cultural aspects in the short, medium and long term [18], [19]. For that reason, researching tourism's impacts in the CRC is very important and cannot be underestimated by interested parties [20], because these parties do not generally take into account the risks that having non-sustainable tourism carries in such areas.

\subsection{Tourism's sustainability indicators}

Tourism requires sustainable planning processes, which ensure that destinations have a stable economy, preserving both their environmental and cultural conditions [21]. The World Tourism Organization (UNWTO) has, for two decades, implemented a set of guiding indicators to determine the sustainability of tourism [22], [23]. The UNWTO guide has been an important point of reference for the scientific community, for certain planning organizations, and for tourism stakeholders. The guide describes key stages in the elaboration and application of STI. These stages can be divided into three categories: design, application and evaluation. It is important to mention that the guide was elaborated by an expert panel from around the world, which guarantees that its application will work in dissimilar scenarios. Therefore, STI as management, planning and monitoring tools have a key role in achieving the sustainability of tourism [24].

The following are the main advantages of using STI:

1. They provide hard data on impacts emanating from the activity;

2. They help to take trends alerts to the host community;

3. They make it possible to redesign and make timely decisions on critical changes in destinations;

4. They provide hard data for the formulation of public policies, guaranteeing a more sustainable management of the consumption of the resources of this activity;

5. They allow continuous evaluation and monitoring of destinations and predict past, present and future scenarios [25], [28].

There are also important criteria that can help to define appropriate indicators for sustainable tourism. First of all, the indicator must be relevant to the destination. Second, it must have availability and quality of reliable data, in order to perform comparative analyses. It must also be possible to measure in time. Finally, it must ensure understandable and feasible results for the parties concerned [15], [23], [27], [29].

\section{METHODOLOGY}

The search for information was based on four databases of academic digital repositories, through a combination of keywords, which facilitate the identification of studies to be examined [6]. Scopus, Wile Online Library, Web of Science and Google Scholar were the repositories that we consulted for this work, by using the advanced search engine of each 
website over a 7-year period (2010-2017). The keywords that we used to search were the following: indicators, sustainable tourism, coastal tourism, tourism in rural areas, rural coastal communities, and coastal areas.

In order to fulfill the objective of this review, this study was divided into three key stages. The first stage was the selection of articles, for which the following criteria were considered:

1. The condition to be selected for was having at least two keywords, between the title and the abstract [9];

2. Clearly point out the indicators that they implemented;

3. They have a study area for their application in the coastal zone; and

4. That one of the authors had at least two published articles on STI.

In the second stage, we grouped the indicators into the three components of sustainability: economic, socio-cultural and environmental. We examined whether the selected articles complied with the recommendations of use of the UNWTO [23]. In order to do so, we listed the indicators proposed by the organization with regard to basic issues, coastal zones, beach sites and destinations that were previously selected, of which we found 74 indicators recognized [7].

In the third stage, we processed the information using the software "Gephi 9.1". A graph was constructed that showed the relationship, author and indicator whose nodes are authorindicator, with the edges being the relations between author-indicators. We analyzed the relations of the indicators according to the use and frequency with which they were used by the authors. According to the main relationships, we selected the key indicators that could be used in the CRC (Fig. 1).

\section{RESULTS AND DISCUSSION}

\subsection{Tourism indicators in the CRC}

In the pursuit of the scientific information that was carried out through the four digital repositories, the following results were found: Wiley online library, (17 articles), Web of Science (6 articles), Google academic (29 articles) and Scopus (20 articles); In total, 72

\begin{tabular}{|cl|}
\hline $\begin{array}{c}\text { Stage 1 } \\
\text { Selection of digital academic } \\
\text { repositories }\end{array}$ & $\begin{array}{l}\text { Article analysis, (OMT, 2004) } \\
\text { Indicators (basics, coastal zones } \\
\text { beach destination, and sites) }\end{array}$ \\
$\qquad$ & IB = Question basic \\
Keyword combination & IZC = Coastal zones \\
$\downarrow$ & ISP = Beach destinations and sites \\
Selection of study criteria & $\downarrow$ \\
& Stage 3 \\
& Relations of indicators \\
(Gephi, 9.1)
\end{tabular}

Figure 1: Methodological process. 
articles were acknowledged according to the parameters of title and the combination of keywords. In the first phase, 20 articles were selected, with a total of 747 indicators.

Taking into account the previously established criteria, we found that only 12 articles met the criteria to be analyzed. We recognized 580 indicators, together with the 74 indicators proposed by the UNWTO. All indicators were grouped into the three basic components of sustainability: economic, socio-cultural and environmental, of which it is important to mention that not all authors indicate this separation; therefore, we used a subjective criterion to be able to have all grouped indicators within these three areas.

On the other hand, the databases used indicated that there is little literature on the subject of STI in CRC; however, the 12 above-mentioned articles were taken back to meet the subject of study and to assign to each a previous list of indicators that could be used in the CRC, as the 12 articles did focus on the definition and study of sustainability indicators in coastal areas.

It is important to mention that according to the research there are several studies that were applied in rural areas (Fig. 2); however, they were more centralized on cultural destinations and to protected areas in non-coastal areas. Therefore, it is necessary to specify that we found only one study was in a CRC, with a small population of no more than 2500 inhabitants. Despite this, the already identified studies in coastal zones are recognized and are very useful for understanding the development of tourism in these areas: This is why there is a need to establish STI. In this sense, the use of indicators to study the impact of tourism in coastal zones can be applied in different scenarios. For example: Diedrich et al. [30] developed indicators for the integral management of coastal zones, through a participatory approach; Logar [31] had provided indicators to measure the impact of tourism on the three pillars of sustainability; Jurado et al. [32] applied synthetic indicators to assess the limits of growth in tourist destinations; Pérez et al. [33] proposed a system of composite indicators for destinations with cultural and natural segments; and Villanueva et al. [34] proposed a model of indicators that can be used to evaluate the monitoring of sustainable development in a coastal zone.

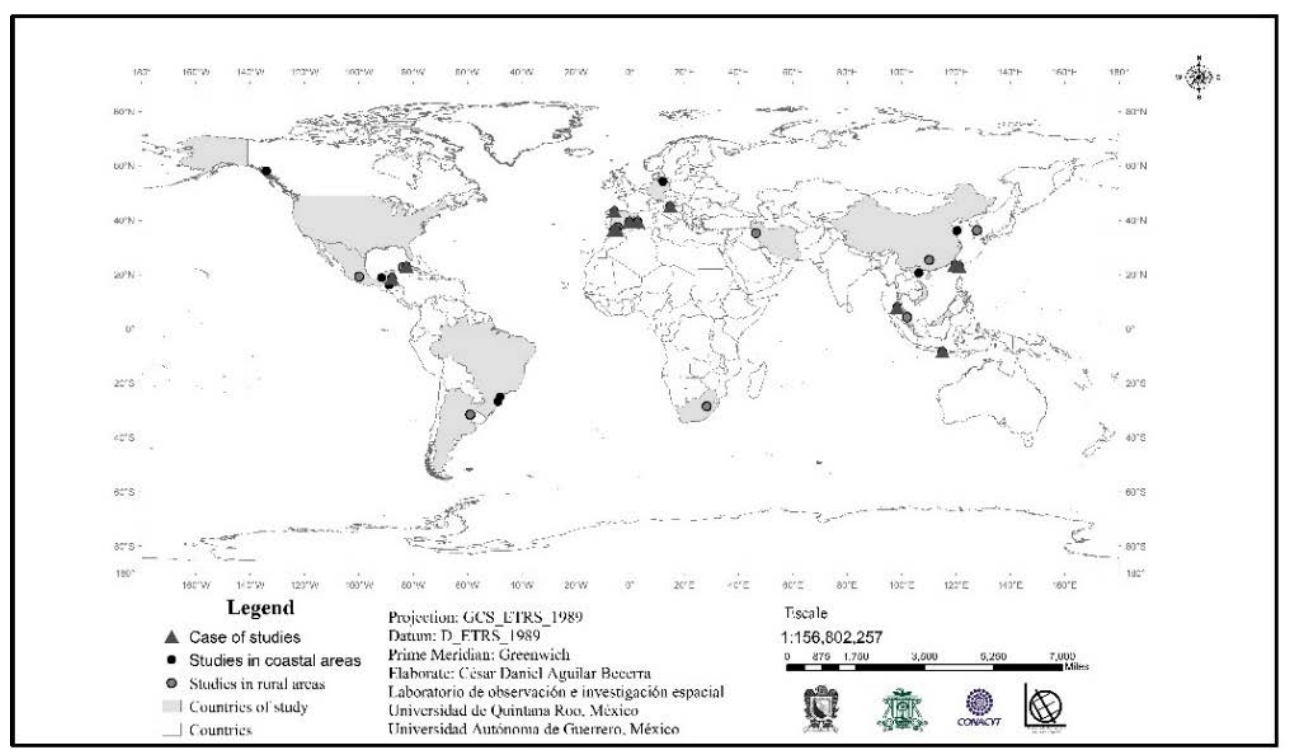

Figure 2: Zoning of sustainable tourism indicators studies, elaborated for this study. 
Table 1: Database of studies analyzed.

\begin{tabular}{|c|c|c|}
\hline Authors & Title & No. ITS \\
\hline [23] & $\begin{array}{l}\text { Indicators of sustainable development for tourism } \\
\text { destinations. A guidebook. }\end{array}$ & 74 \\
\hline [30] & $\begin{array}{l}\text { Balancing science and society through establishing } \\
\text { indicators for integrated coastal zone management in the } \\
\text { Balearic Islands. }\end{array}$ & 54 \\
\hline [15] & $\begin{array}{l}\text { The assessment of sustainable tourism: Application to } \\
\text { Spanish coastal destinations. }\end{array}$ & 32 \\
\hline [31] & $\begin{array}{l}\text { Sustainable tourism management in Crikvenica, Croatia: } \\
\text { An assessment of policy instruments. }\end{array}$ & 27 \\
\hline [32] & $\begin{array}{l}\text { Carrying capacity assessment for tourist destinations. } \\
\text { Methodology for the creation of synthetic indicators } \\
\text { applied in a coastal area. }\end{array}$ & 24 \\
\hline [33] & $\begin{array}{l}\text { Composite indicator for the assessment of sustainability: } \\
\text { The case of Cuban nature-based tourism destinations. }\end{array}$ & 39 \\
\hline [34] & $\begin{array}{l}\text { Model of indicators for evaluation and monitoring of } \\
\text { sustainable development in the coastal area of Mahahual, } \\
\text { Quintana Roo, Mexico. }\end{array}$ & 26 \\
\hline [35] & $\begin{array}{l}\text { Investigating the importance of surf resource } \\
\text { sustainability indicators: Stakeholder perspectives for } \\
\text { surf tourism: Planning and development. }\end{array}$ & 27 \\
\hline [36] & $\begin{array}{l}\text { A system of synthetic indicators for the diagnosis of } \\
\text { regulated tourist areas of the Valencian coast. }\end{array}$ & 22 \\
\hline [37] & $\begin{array}{l}\text { Performance indicator framework for evaluation of } \\
\text { sustainable tourism in the Taiwan Coastal Zone. }\end{array}$ & 26 \\
\hline [38] & $\begin{array}{l}\text { Indicators of sustainable tourism: A case study from a } \\
\text { Taiwanese wetland. }\end{array}$ & 141 \\
\hline [39] & $\begin{array}{l}\text { A green economy indicator framework for tourism } \\
\text { destinations. }\end{array}$ & 119 \\
\hline [40] & $\begin{array}{l}\text { Developing a system of territorial governance indicators } \\
\text { for tourism destinations. }\end{array}$ & 43 \\
\hline
\end{tabular}

Given this situation, the selected studies have different study objectives. As a result, there is no number of homogeneous indicators in relation to each of them, and in addition to this, it should be noted that the coastal areas where the studies were applied have different characteristics; therefore, we deduced why each author handles different types of indicators and methods for the construction of their system or base of indicators. However, out of the selected studies, several authors have, in their methodological process, come to a panel of experts in tourism of diverse disciplines, with the objective of determining important aspects regarding the sustainability of an activity. According to the information above, determining the number of indicators and the scope of each indicator so that they 
can be applied in their studies (e.g. [30], [32], [37], [38]) is useful; however, not all studies view all stakeholders in the development of their STI.

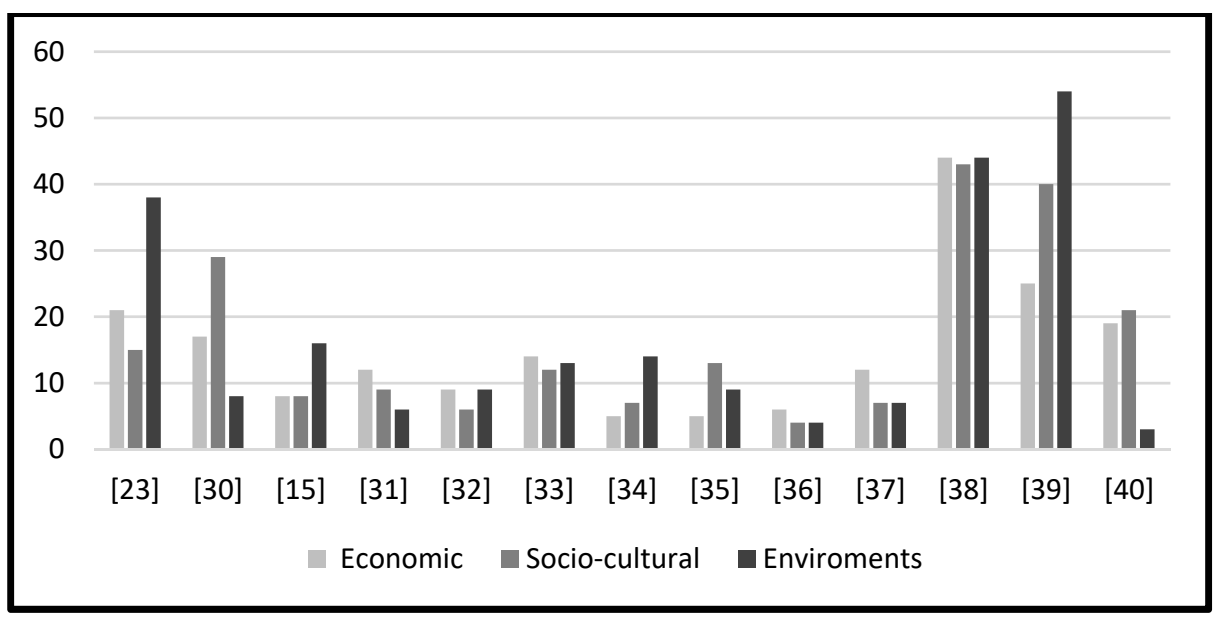

Figure 3: Grouping of indicators.

On the other hand, for the grouping of indicators, our findings indicate that the three important areas of sustainability were not balanced, as for the use of the number of indicators in each area (Fig. 3). Although there is no specific number of parameters for indicators that determine sustainability in these destinations, we recognize that there is a need for a counterweight in each area and for each indicator, because a poor choice of indicators can falsify the dimensions of the sustainability of tourism [7]. In this sense, it is recommended that the goals and objectives for the selection of STIs are identified first, taking into account the risks and problems of the development and construction of tourism in the host destinations, and considering the participation of the interested parties throughout the process [30].

\subsection{Relationship analysis}

The study of relationships as a key element to understanding the tourism phenomenon is important [41]. In the case of this study, it was important to relate the indicators recommended by WTO [23] with the indicators used by the authors of the studies selected.

In total there were 86 nodes, 12 nodes that correspond to the authors and 74 nodes to the indicators, with 147 perspectives in total. According to the information above, out of the 74 indicators selected by the WTO, 70\% were used and showed some relation; however, the percentage may be reduced if only 6 indicators are considered to have between one and three relationships, and to represent $47 \%$ of the total. In turn, $23 \%$ of the total indicators had more than four relationships, and in the remaining 30\%, no relationship was found (Fig. 4).

On the other hand, taking into account that the author-indicator nodes recognize five authors with the highest degree of nodes, that is, they concentrate the highest number of edges according to the main author-indicator relationships. The author with the highest number of relationships was Blancas et al. [15], with 27 indicators in relation to those recommended by the UNWTO. One of the indicators that applied the most in the different studies analyzed is the IB10 (the number of jobs generated by tourism in the destination), 
IB5 (the tourism satisfaction level) and IB12 (the tourism revenue as a percentage of total community income). It is important to mention that of the indicators of recommended basic issues of tourism, the UNWTO-created ones are the ones that have the most relationships with case studies (Table 2).

Accordingly, 17 indicators are considered to be applied in CRC: five are social, six are economic and six are environmental; however, it is important to mention that they are mostly related to basic issues, so it is recommended that in subsequent studies, the comparison should be made only among the authors.

\section{CONCLUSIONS}

This study is innovative, given that the case studies are very different; but the objectives of the study were achieved. Likewise, through the relationships obtained, we were able to explore the feasibility of implementing key indicators in the CRC, since the final list of STI can be a starting point for their implementation in themselves. In this sense, the selected STI may be comparable in dissimilar scenarios. On the other hand, considering the school by the formulation of up-down indicators may be feasible for consideration of STI in CRC; however, we recommend also using the bottom-up schools and taking into account the stakeholders, as well as experts for their validation.

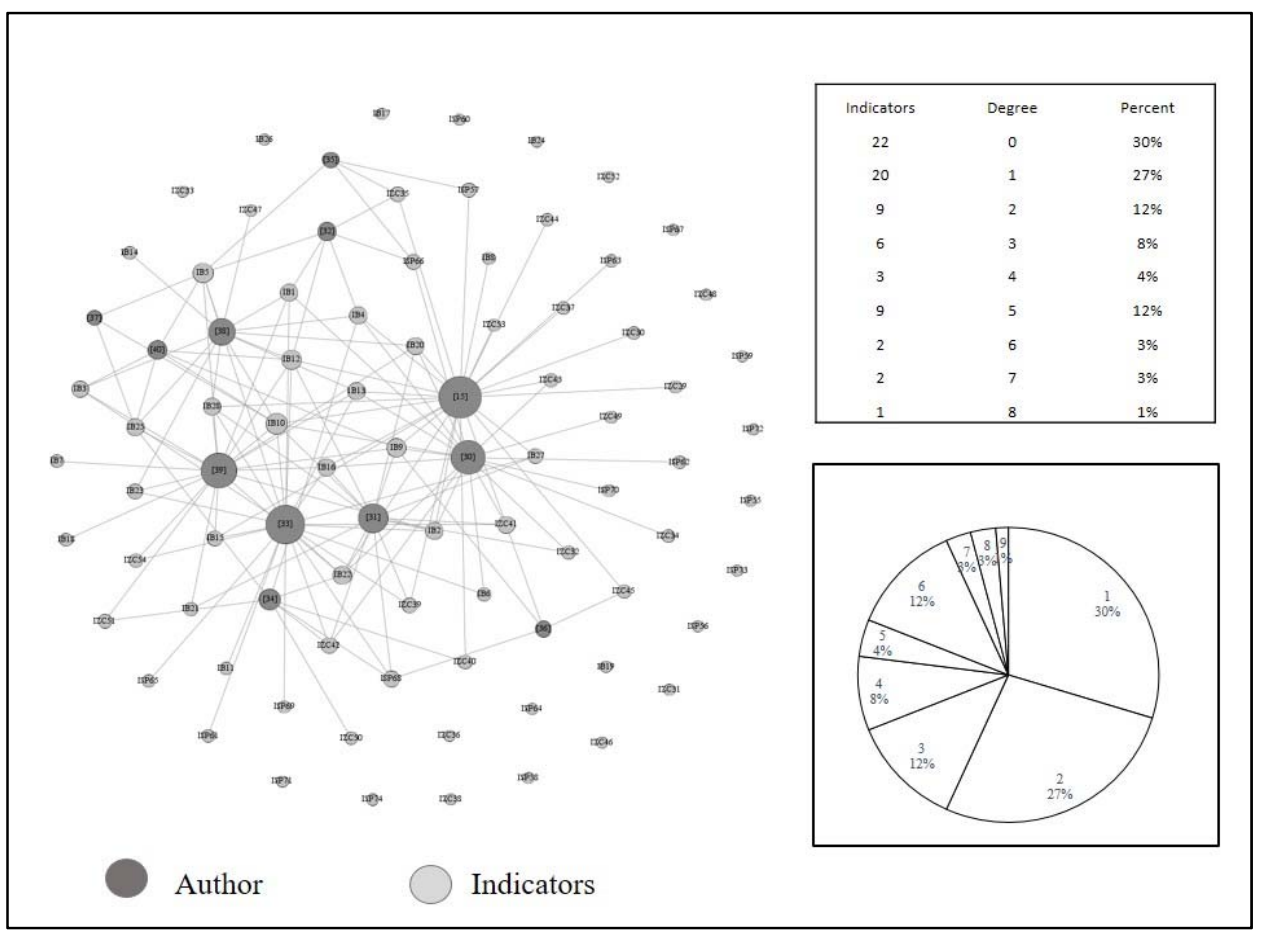

Figure 4: Relationship between author-indicator. The degree of the node-author shows the number of indicators that the author uses, and the degree of the nodeindicator is the amount of authors that apply it in their studies. The node-author relationships that have a higher degree are the ones that have the highest number of indicators related to the recommendations of UNWTO, and the degree of the node associated with the indicator shows the number of times that it was applied. 
Table 2: List of the most-used indicators (in the cases studied).

\begin{tabular}{|c|c|c|}
\hline ID & $\begin{array}{c}\text { Frequenc } \\
y\end{array}$ & Indicators \\
\hline IB1 & 5 & Level of satisfaction from the residents with the tourism \\
\hline IB3 & 4 & $\begin{array}{l}\text { Percentage of people who believe that tourism has helped } \\
\text { to create new substructure services }\end{array}$ \\
\hline IB2 & 5 & Percentage among tourists and native population \\
\hline IB4 & 5 & $\begin{array}{l}\text { Amount and capacity of social services available for the } \\
\text { community }\end{array}$ \\
\hline IB5 & 7 & Level of satisfaction among tourists \\
\hline IB9 & 6 & Monthly occupation rates of authorized accommodations \\
\hline IB10 & 8 & $\begin{array}{l}\text { Amount and percentage of workstations from the tourist } \\
\text { section that are permanent or annual }\end{array}$ \\
\hline 1B12 & 7 & $\begin{array}{l}\text { Income generated by tourism as an overall percentage of } \\
\text { income generated by the community }\end{array}$ \\
\hline IB13 & 5 & Intake per capita of energy from all sources \\
\hline IB16 & 5 & $\begin{array}{l}\text { Water used: total volume consumed and liters per tourist } \\
\text { and day }\end{array}$ \\
\hline IB20 & 6 & $\begin{array}{l}\text { Percentage of sewage water from the zone that gets } \\
\text { treatment }\end{array}$ \\
\hline IB22 & 5 & Volume of waste produced by the destination \\
\hline IB25 & 5 & $\begin{array}{l}\text { Existence of any territorial or developmental planning } \\
\text { process that is related to tourism }\end{array}$ \\
\hline IB28 & 5 & Number of tourists per square meter from the site \\
\hline IZC41 & 5 & $\begin{array}{l}\text { Level of occupation (of accommodations) throughout the } \\
\text { year }\end{array}$ \\
\hline IZC42 & 4 & $\begin{array}{l}\text { Percentage of employment in the tourist sector with } \\
\text { contracts for less than } 6 \text { months }\end{array}$ \\
\hline ISP68 & 4 & Number of bathrooms and showers per beach \\
\hline
\end{tabular}

On the other hand, the review made it clear what are the UNWTO indicators that are being used in recent years in the coastal zones, and it was shown that there is little literature regarding the application of STIs in CRC.

\section{ACKNOWLEDGEMENTS}

We thank the University of Quintana Roo for the use of their facilities for consulting literature, especially the research and special observation laboratory. We thank the Autonomous University of Guerrero for the economic support that made this research possible, such as CONACYT for the scholarship granted for doctoral studies. In addition, we thank program colleagues Janet Arellano Wences and Jair de Jesús Pineda Pineda. 


\section{REFERENCES}

[1] McAreavey, R. \& McDonagh, J., Sustainable rural tourism: Lessons for rural development. Sociologia ruralis, 51(2), pp. 175-194, 2011.

[2] Davenport, J. \& Davenport, J.L., The impact of tourism and personal leisure transport on coastal environments: a review. Estuarine, Coastal and Shelf Science, 67(1), pp. 280-292, 2006.

[3] Lozano-Oyola, M., Blancas, F.J., González, M. \& Caballero, R., Sustainable tourism indicators as planning tools in cultural destinations. Ecological Indicators, 18, pp. 659-675, 2012.

[4] Diedrich, A. \& García-Buades, E., Local perceptions of tourism as indicators of destination decline. Tourism Management, 30(4), pp. 512-521, 2009.

[5] Pomeranz, E.F., Needham, M.D. \& Kruger, L., Stakeholder perceptions of indicators of tourism use and codes of conduct in a coastal protected area in Alaska. Tourism in Marine Environments, 9(1-2), pp. 95-115, 2013.

[6] Chang, W.J. \& Katrichis, J.M., A literature review of tourism management (19902013): a content analysis perspective. Current Issues in Tourism, 19(8), pp. 791-823, 2016.

[7] Tanguay, G.A., Rajaonson, J. \& Therrien, M.C., Sustainable tourism indicators: Selection criteria for policy implementation and scientific recognition. Journal of Sustainable Tourism, 21(6), pp. 862-879, 2013.

[8] Torres-Delgado, A. \& Saarinen, J., Using indicators to assess sustainable tourism development: a review. Tourism Geographies, 16(1), pp. 31-47, 2014.

[9] Falatooni, E., Selen, W. \& Kerr, D., A new framework for selecting composite indicators to assess sustainability of a destination. Athens Journal of Tourism, 3(1), pp. 7-24, 2016.

[10] United Nations Educational, Scientific and Cultural Organization (UNESCO), Online. www.unesco.org/new/en/education/themes/strengthening-education/systems/ inclusive-education/rural-people/. Accessed on: 17 Apr. 2017.

[11] Instituto Nacional de Estadística y Geografía (INEGI),. Información por identidad federativa, Online. www.cuentame.inegi.org.mx. Accessed on: 30 Mar. 2017.

[12] Frochot, I., A benefit segmentation of tourists in rural areas: a Scottish perspective. Tourism Management, 26(3), pp. 335-346, 2005.

[13] Lanfranchi, M., Giannetto, C. \& De Pascale, A., The link between economic growth and environmental quality in the case of coastal tourism in the rural areas. Applied Mathematical Sciences, 9(35), pp. 1745-1755, 2015.

[14] Matarrita, C.D., Changing communities, community satisfaction, and quality of life: A view of multiple perceived indicators. Social Indicators Research, 98(1), pp. 105$127,2010$.

[15] Blancas, F.J., González, M., Lozano-Oyola, M. \& Perez, F., The assessment of sustainable tourism: Application to Spanish coastal destinations. Ecological indicators, 10(2), pp. 484-492, 2010.

[16] Pirlone, F. \& Spadaro, I., Sustainable Tourism Action Plan in The Mediterranean Coastal Areas. International Journal of Sustainable Development and Planning, 12(6), pp. 995-1005, 2017.

[17] Marzo-Navarro, M., Pedraja-Iglesias, M. \& Vinzón, L., Sustainability indicators of rural tourism from the perspective of the residents. Tourism Geographies, 17(4), pp. 586-602, 2015.

[18] Gladstone, W., Curley, B. \& Shokri, M.R., Environmental impacts of tourism in the Gulf and the Red Sea. Marine pollution bulletin, 72(2), pp. 375-388, 2013. 
[19] Cialdea, D. \& Mastronardi, L., Integrated approach in the planning stage for landscape conservation in the Coastal Italian Areas. International Journal of Design \& Nature and Ecodynamics, 9(4), pp. 296-306, 2014.

[20] Deery, M., Jago, L. \& Fredline, L., Rethinking social impacts of tourism research: A new research agenda. Tourism Management, 33(1), pp. 64-73, 2012.

[21] Núñez-Lara, E., Cahuich-Carrillo, A., Delgado-Estrella, A. \& Laffon-Leal, S., Tourism and sustainability indicators as planning tools for a coastal NPA in Mexico. WIT Transactions on Ecology and the Environment, 193, pp. 355-364, 2015.

[22] World Tourism Organization, what tourism managers need to know. A practical guide to the development and use of indicators of sustainable tourism, World tourism Organization: Spain, 1996.

[23] World Tourism Organization., Indicators of Sustainable Development For tourism destinations. A guidebook, World Tourism Organization: Spain, 2004.

[24] Miller, G. \& Twining-Ward, L., Monitoring for a sustainable tourism transition: The challenge of developing and using indicators. Cabi. 2016

[25] Cabello, J. M., Navarro, E., Prieto, F., Rodríguez, B. \& Ruiz, F., Multicriteria development of synthetic indicators of the environmental profile of the Spanish regions. Ecological Indicators, 39, pp. 10-23, 2014.

[26] Mikulić, J., Kožić, I. \& Krešić, D., Weighting indicators of tourism sustainability: A critical note. Ecological Indicators, 48, pp. 312-314, 2015.

[27] Cerutti, A.K., Beccaro, G.L., Bruun, S., Donno, D., Bonvegna, L. \& Bounous, G., Assessment methods for sustainable tourism declarations: The case of holiday farms. Journal of Cleaner Production, 111, pp. 511-519, 2016.

[28] Choi, H.C. \& Sirakaya, E., Sustainability indicators for managing community tourism. Tourism management, 27(6), 1274-1289, 2006.

[29] Park, D.B. \& Yoon, Y.S., Developing sustainable rural tourism evaluation indicators. International Journal of Tourism Research, 13(5), pp. 401-415, 2011.

[30] Diedrich, A., Tintoré, J. \& Navinés, F., Balancing science and society through establishing indicators for integrated coastal zone management in the Balearic Islands. Marine Policy, 34(4), pp. 772-781, 2010.

[31] Logar, I., Sustainable tourism management in Crikvenica, Croatia: An assessment of policy instruments. Tourism management, 31(1), pp. 125-135, 2010.

[32] Jurado, E.N. et al., Carrying capacity assessment for tourist destinations. Methodology for the creation of synthetic indicators applied in a coastal area. Tourism Management, 33(6), pp. 1337-1346, 2012.

[33] Pérez, V., Guerrero, F., González, M., Pérez, F. \& Caballero, R., Composite indicator for the assessment of sustainability: The case of Cuban nature-based tourism destinations. Ecological Indicators, 29, pp. 316-324, 2013.

[34] Villanueva, L.C. et al., Modelo de indicadores para la evaluación y monitoreo del desarrollo sustentable en la zona costera de Mahahual, Quintana Roo, México. Perspectiva Geográfica, 19(2), pp. 309-330, 2016.

[35] Martin, S.A. \& Assenov, I., Investigating the Importance of Surf Resource Sustainability Indicators: Stakeholder Perspectives for Surf Tourism Planning and Development. Tourism Planning \& Development, 11(2), pp. 127-148, 2014.

[36] Temes, R., A System of Synthetic Indicators for the Diagnosis of Regulated Tourist Areas of the Valencian Coast. WIT Transactions on Ecology and the Environment, 191, pp. 259-269, 2014. 
814 Sustainable Development and Planning IX

[37] Wang, S.H., Lee, M.T., Château, P.A. \& Chang, Y.C., Performance Indicator Framework for Evaluation of Sustainable Tourism in the Taiwan Coastal Zone. Sustainability, 8(7), pp. 652, 2016.

[38] Lee, T.H. \& Hsieh, H.P., Indicators of sustainable tourism: A case study from a Taiwan's wetland. Ecological Indicators, 67, pp. 779-787, 2016.

[39] Law, A., DeLacy, T. \& McGrath, G.M., A green economy indicator framework for tourism destinations. Journal of Sustainable Tourism, pp. 1-22, 2017.

[40] Fernández-Tabales, A., Foronda-Robles, C., Galindo-Pérez-de-Azpillaga, L. \& García-López, A., Developing a system of territorial governance indicators for tourism destinations. Journal of Sustainable Tourism, pp. 1-31, 2017.

[41] Merinero-Rodríguez, R. \& Pulido-Fernández, J.I., Analysing relationships in tourism: A review. Tourism Management, 54, pp. 122-135, 2016. 